ISSN : 2303-1514 | E-ISSN : 2598-5949

\title{
LITERACY IN THE MIDST OF THE PANDEMIC: HOW ARE STUDENTS' LITERACY SKILLS?
}

\author{
Arif Widodo ${ }^{1}$, Umar $^{2}$ \\ ${ }^{1,2}$ Universitas Mataram, Indonesia \\ 1arifwidodo@unram.ac.id, ${ }^{2}$ umarelmubaraq90@unram.ac.id
}

\section{LITERASI DI TENGAH PANDEMI: BAGAIMANA KEMAMPUAN LITERASI SISWA}

\begin{abstract}
ARTICLE HISTORY
ABSTRACT

Abstract: During the pandemic, learning at elementary schools encountered many obstacles, including those related to literacy. One indicator of basic literacy skills is that having reading fluency and comprehension. During the pandemic, how are students' basic literacy skills? This study aimed to determine the profile of students' basic literacy skills during the pandemic. This study was conducted at one of the public elementary schools in Kabupaten Lombok Tengah. This study was survey research that administered a test as the instrument. The research subjects were 110 students who were selected saturated sampling technique. Data were

Submitted:

10 Juli 2021

$10^{\text {th }}$ July 2021 analyzed using descriptive statistics. The survey results showed that $7 \%$ of the students were at the beginner level is $7 \%$, while $10 \%$ of students were at the letter level. Then, $11 \%$ of the students were at the word level; $12 \%$ of them were at the paragraph level; $12 \%$ of students were at story one level as much as $12 \%$, and $48 \%$ of students were at story level. Most of the students were not fluent in reading and could not understand the reading content. Students who were fluent in reading and able to understand the text were less than half of the population or only $48 \%$ of 110 students. These data indicated a decline in students' basic literacy skills during learning in the pandemic era.
\end{abstract}

Accepted:

20 September 2021

$20^{\text {th }}$ September 2021

Published:

28 Oktober 2021

$28^{\text {th }}$ October 2021

Keywords: literacy, pandemic era, elementary school

Abstrak: Selama pandemi pembelajaran di sekolah dasar banyak mengalami hambatan, termasuk di dalamanya yang berkaitan dengan literasi. Salah satu indikator dari kemampuan literasi dasar adalah siswa lancar membaca dan mampu memahami apa yang dibaca. Dengan adanya pandemi bagaimana kemampuan literasi dasar siswa? Penelitian ini bertujuan untuk mengetahui profil kemampuan literasi dasar siswa selama pandemi. Penelitan dilakukan pada salah satu sekolah dasar negeri di kabupaten Lombok Tengah. Penelitian menggunakan teknik survei. Instrumen yang digunakan berupa tes. Subjek penelitian sebanyak 110 siswa. Pengambilan sampel menggunakan teknik sampling jenuh. Data dianalisis menggunakan statistik deskriptif. Hasil survei memperlihatkan bahwa jumlah siswa pada level pemula sebanyak $7 \%$, pada level huruf $10 \%$, pada level kata sebanyak $11 \%$, level paragraf $12 \%$, level cerita satu sebanyak 12\% dan level cerita dua sebanyak 48\%. Sebagian besar siswa belum lancar membaca dan tidak dapat memahami isi bacaan. Siswa yang lancar membaca dan mampu memahami apa yang dibaca kurang dari setengah populasi atau hanya $48 \%$ dari 110 siswa. Data tersebut mengindikasikan adanya penurunan kemampuan literasi dasar siswa selama pembelajaran di era pandemi.

Kata Kunci: literasi dasar, era pandemi, sekolah dasar

\section{CITATION}

Widodo, A., \& Umar, U. (2021). Literacy in the Midst of the Pandemic: How are Students' Literacy Skills?. Primary: Jurnal Pendidikan Guru Sekolah Dasar, 10 (5), 1199 1206. DOI: http://dx.doi.org/10.33578/jpfkip.v10i5.8506.

\section{PENDAHULUAN}

Literasi dasar mencakup keterampilan berbicara, menyimak, membaca dan menulis. Keterampilan dasar ini menjadi modal utama siswa dalam mengembangkan pengetahuan.
Selain itu, keterampilan tersebut merupakan bekal siswa agar mampu hidup bersosial di lingkungan masyarakat. Dari beberapa ruang lingkup literasi tersebut, membaca menempati posisi yang paling utama dalam kegiatan 
literasi (Endiawan, Fathurohman, \& Santoso, 2020). Seorang siswa harus menjadi pembaca yang baik sebelum belajar berbicara, menyimak dan menulis. Tanpa membaca seorang siswa tidak akan mampu mengembangkan pengetahuan dengan baik (Budiati, 2013). Namun demikian, hal terpenting dalam membaca adalah memahami isi bacaan. Dengan memahami isi bacaan siswa dapat mengambil informasi dan pesan yang terdapat dalam teks. Oleh karena itu dalam literasi dasar siswa diharapkan tidak hanya membaca dengan lancar tetapi juga mampu memahami isi bacaan tersebut.

Terdapat penelitian yang menyebutkan bahwa membaca memiliki manfaat yang sangat baik bagi kesehatan otak, dapat meningkatkan kecerdasan logika, dan linguistik (Batubara \& Ariani, 2018). Siswa yang rajin membaca biasanya lebih mudah memahami persoalan yang dihadapi dalam kehidupan sehari-hari. Selain itu siswa yang rajin membaca pada umumnya memiliki kemampuan menulis yang lebih baik. Hal ini berkaitan dengan aktivitas pascabaca yang sangat penting bagi siswa, salah satunya adalah menulis rangkuman atau intisari bacaan (Ratnawati, 2018). Aktivitas pascabaca inilah yang sangat penting untuk dikuasai siswa karena berkaitan dengan pengembangaan keterampilan dan pengetahuan siswa ke level yang lebih tinggi. Menurut Howard Gardner, pencetus teori kecerdasan majemuk pada hakekatnya manusia memiliki delapan kecerdasan, yaitu linguistik, matematika, spasial, kinestetis, musik, intrapersonal, interpersonal, dan naturalis (Antoro, 2017). Semua potensi yang dimiliki manusia itu menyatu dalam jiwa raga dan tak terpisahkan. Tugas manusia adalah merangsang semua kecerdasan tersebut agar tumbuh dan berkembang dengan baik. Cara terbaik untuk merangsang kemampuan tersebut adalah dengan membaca. Tugas yang paling penting dari seorang guru adalah mampu memfasilitasi siswa agar dapat belajar membaca dengan baik.
Tugas guru dalam mengajarkan literasi di sekolah dasar tidaklah mudah. Terlebih lagi dalam pembelajaran di tengah pandemi. Pola kegiatan literasi di sekolah dasar yang disajikan dalam buku tematik ada dua belas pola. Pola yang paling sederhana adalah pola skemata-baca-tulis, sedangkan yang paling kompleks adalah pola pertanyaan-baca-tulis (Suyono, Harsiati, \& Wulandari, 2014). Pada dasarnya pola literasi yang disajikan dalam buku tematik sudah cukup lengkap, namun dengan adanya pandemi pola literasi yang dilakukan tidak sesuai dengan harapan. Sedikitnya pertemuan tatap muka dan berbagai pembatasan yang lain dalam kegiatan pembelajaran selama pendemi membuat program literasi terhambat (Lilawati, 2020). Kondisi semacam ini merupakan ancaman bagi perkembangan kemampuan literasi dasar siswa. Dengan terhambatnya program literasi di sekolah akan menyebabkan penurunan kemampuan membaca siswa. Implikasinya adalah penguasaan literasi dasar dan gerakan literasi nasional yang diprogramkan pemerintah tidak akan tercapai. Terlebih lagi dengan akan diberlakukannya asesmen nasional yang salah satu unsur penilainnya adalah kemampuan literasi dasar, tentunya kegiatan literasi harus mendapatkan perhatian yang lebih.

Berawal dari penjelasan yang telah disampaikan perlu dilakukan survei terhadap kemampuan literasi dasar siswa. Penelitian ini bertujuan untuk mengetahui bagaimana kemampun literasi dasar siswa selama pembelajaran di era pandemi. Penelitian ini penting dilakukan sebagai bahan evaluasi terhadap efektifitas pembelajaran selama pandemi di sekolah dasar. Agar evaluasi yang dilakukan tepat sasaran maka perlunya mengetahui level kemampuan literasi dasar siswa. Problem utama yang dikaji dalam penelitian ini adalah: bagaimana kemampuan literasi dasar siswa selama pandemi? seberapa besar jumlah siswa yang telah menguasai literasi dasar? Melalui penelitian ini diharapkan dapat menjadi dasar dalam 
melakukan perbaikan dalam pembelajaran literasi di era pandemi.

\section{KAJIAN TEORI \\ Literasi Dasar}

Literasi secara umum tidak hanya berkutat pada kemampuan membaca dan menulis, tetapi juga berkaitan dengan kemampuan numerasi, literasi digital, literasi budaya, literasi global dan literasi kewarganegaraan (Saryono et al., 2017). Sedikit berbeda jika literasi hanya dibatasi pada pengertian literasi dasar. Literasi dasar mencakup empat aspek utama, yaitu kemampuan berbicara, menyimak, membaca dan menulis. Literasi dasar pada awalnya hanya mencakup kegiatan membaca dan menulis. Jika seseorang telah memiliki dua kemampuan tersebut maka orang tersebut dapat dikatakan literat (Wiedarti \& Laksono, 2016). Literasi dalam konteks yang lebih sederhana merupakan kemampuan dalam memahami informasi, mengelola informasi dan menggunakan informasi tersebut dalam berbagai konteks (Sujana \& Rachmatin, 2019). Literasi juga dapat diartikan sebagai kemampuan dalam menelaah dan mengelola informasi agar dapat bermanfaat bagi manusia. Kemampuan dalam mempelajari serta mengolah informasi merupakan modal utama bagi seorang siswa dalam mengembangkan pengetahuan, cara berpikir maupun pengembangan perilaku dan karakter. Dengan memiliki kemampuan dalam mengolah informasi secara tepat seseorang dapat lebih bijaksana, kritis dan teliti sehingga terhindar dari pemahaman yang salah terhadap informasi (Juliswara, 2017).

\section{Pembelajaran di era Pandemi}

Pandemi telah merubah tatanan dunia dengan cepat. Salah satu aspek yang terkena dampaknya adalah dunia pendidikan. Konsekuensi yang harus diterima dunia pendidikan di tengah pandemi ini adalah dengan diberlakukannya pembelajaran jarak jauh (Indahri, 2020). Pada dasarnya pembelajaran jarak jauh dalam implementasinya menyesuaikan dengan kondisi masing-masing sekolah. Setidaknya terdapat dua jenis model pembelajaran jarak jauh yang lazim digunakan selama pandemi yaitu melalui daring (dalam jaringan) dan luring (luar jaringan). Dalam pembelajaran daring masing-masing guru dapat menyesuaikan media pembelajaran sesuai dengan kemampuan yang dimilikinya. Guru dituntut untuk melakukan inovasi dan kreasi agar pembelajaran dapat efektif (Sutisna \& Widodo, 2020). Sebagian guru ada yang mengoptimalkan penggunaanWhatsApp, ada yang menggunakan You Tube dan beberapa aplikasi populer lainnya. Namun demikian penggunaan media daring ini memiliki banyak kelemahan, seperti signal yang kurang stabil, penguasaan teknologi kurang, biaya tinggi serta tidak tersedianya sarana dan prasarana pendukung. Implikasinya adalah para guru lebih memilih untuk melakukan pembelajaran secara luring. Dalam pembelajaran luring biasanya siswa dibagi dalam beberapa kelompok kecil sesuai daerah tempat tinggal siswa. Guru melakukan kunjungan dengan durasi waktu yang sangat terbatas. Kelemahan dalam pembelajaran luring ini adalah guru lebih banyak menghabiskan waktu di jalan sehingga waktu pembelajaran seringkali terpotong. Salah satu bentuk model pembelajaran luring selain guru berkunjung ke kelompok belajar siswa adalah belajar dari rumah (BDR). Model inilah yang banyak diterapkan untuk menghindari penularan wabah yang lebih luas. Pada dasarnya program pembelajaran jarak jauh yang diterapkan selama pandemi, jika diterapkan dengan baik dapat mempercepat terwujudnya program merdeka belajar dari pemerintah (Saleh, 2020).

\section{METODE PENELITIAN}

Penelitian menggunakan teknik survei. Lokasi penelitian di salah satu sekolah dasar negeri di kabupaten Lombok Tengah. Subjek penelitiannya adalah siswa SD dengan jumlah 110 siswa. Pengambilan sampel penelitian 
menggunakan teknik sampling penuh atau menggunakan populasi menjadi subjek penelitian. Pengumpulan data menggunakan instrumen tes literasi dasar. Tes yang digunakan adalah tes membaca. Siswa dibagi menjadi lima kategori, yaitu level pemula, level kata, level paragraf, serta level cerita 1 dan 2. Demikian juga tes yang disajikan disesuaikan sebanyak level kemampuan siswa. Sebelum tes dilakukan terlebih dahulu ditentukan indikator tiap level kemampuan literasi siswa. Siswa yang belum mengenal huruf sama sekali dimasukkan dalam level pemula. Siswa yang mampu mengenal huruf dan ketika membaca tidak salah sebanyak tiga huruf atau lebih maka siswa dimasukkan ke dalam level huruf. Indikator siswa pada level kata adalah tidak salah tiga kata atau lebih ketika membaca kata yang disajikan dalam tes. Siswa yang belum lancar membaca, tetapi tidak salah tiga kata atau lebih pada saat membaca paragraf maka dimasukkan dalam level paragraf. Untuk level cerita hanya siswa yang mampu membaca dengan lancar baik intonasi,tanda baca maupun kelancarannya. Level cerita dibagi menjadi dua. Jika siswa mampu menjawab pertanyaan dengan benar maka siswa dimasukkan dalam level cerita 2, namun jika tidak mampu mennjawab dengan benar maka siswa dimasukkan level cerita 1 . Data dianalisis menggunakan statistik deskriptif. Setelah dilakukan tes kemudian data ditabulasi untuk mengetahui persentase pada masing-masing level literasi. Tabel 1 akan menunjukkan rubrik pengumpulan data kemampuan literasi dasar siswa.

Tabel 1. Rubrik Pengumpulan Data

\begin{tabular}{|c|c|c|c|c|c|c|c|c|}
\hline \multirow[t]{3}{*}{ No. } & \multirow[t]{3}{*}{ Nama Siswa } & \multirow[t]{3}{*}{$\mathrm{L} / \mathrm{P}$} & \multicolumn{6}{|c|}{ Level } \\
\hline & & & \multirow{2}{*}{ Pemula } & \multirow{2}{*}{ Huruf } & \multirow[t]{2}{*}{ Kata } & \multirow{2}{*}{ Paragraf } & \multicolumn{2}{|c|}{ Cerita } \\
\hline & & & & & & & Cerita 1 & Cerita 2 \\
\hline
\end{tabular}

\section{HASIL DAN PEMBAHASAN}

Pengelompokan level kemampuan siswa berdasarkan tes kemampuan membaca. Aturan membaca dimulai dari level paragraf. Jika siswa salah membaca tiga huruf atau kata pada level yang diujikan maka siswa diturunkan ke level yang lebih rendah. Jika pada level tersebut siswa masih salah maka siswa di turunkan levelnya dan diuji lagi pada level tersebut sampai ditemukan level yang tepat. Jika siswa tidak membuat kesalahan dalam membaca maka siswa akan dinaikkan levelnya. Level tertinggi yang dapat dicapai adalah level cerita 2 .

\section{Level kemampuan literasi dasar siswa}

Berdasarkan hasil tes kemampuan membaca dapat ditemukan level kemampuan literasi siswa. Berikut ini dapat disajikan data hasil tes membaca siswa. 


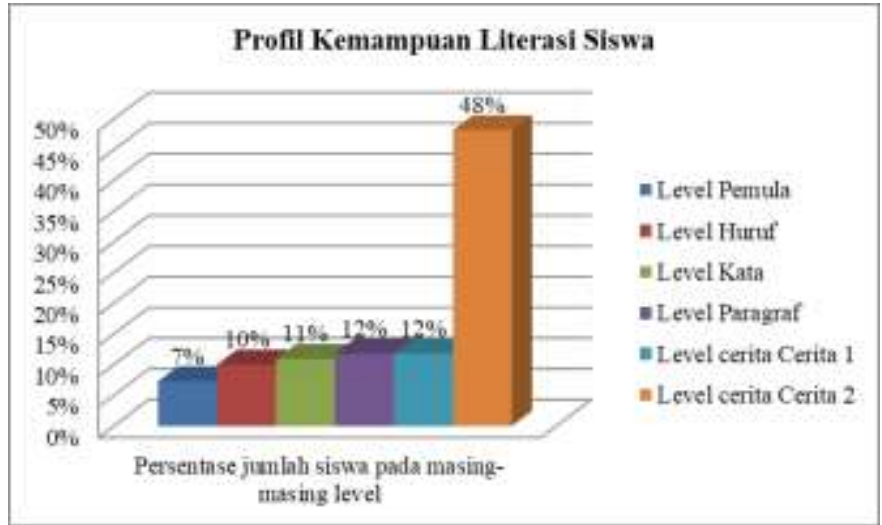

Gambar 1. Profil Kemampuan Literasi Siswa

Berdasarkan gambar 1 dapat diketahui bahwa jumlah siswa yang masih berada di level pemula sebesar 7\% dari 110 siswa atau sebanyak. 8 siswa. Siswa yang dimasukkan dalam level pemula adalah siswa yang belum mengenal huruf sama sekali atau hanya mengenal sebagian huruf saja. Jumlah siswa yang masuk ke dalam level huruf sebesar $10 \%$ atau 11 dari 110 siswa. Siswa dimasukkan ke dalam level huruf jika hanya mampu mengenali huruf namun belum bisa membaca rangkaian huruf menjadi kata. Siswa yang masuk dalam level kata sebesar $11 \%$ atau12 dari 110 siswa. Siswa dimasukkan ke dalam level kata apabila hanya mampu membaca kata-kata yang familiar dan belum mampu membaca paragraf secara utuh. Jumlah siswa pada level paragraf dan cerita 1 masing-masing sebesar $12 \%$ atau sebanyak 13 dari 110 siswa. Siswa dimasukkan ke dalam level paragraf jika telah mampu membaca paragraf secara utuh dan memiliki kesalahan membaca tidak lebih dari tiga kata. Siswa yang mampu membaca pargraf dengan betul namun dari segi kelancarannya masih kurang atau masih mengeja maka siswa ditetapkan dilevel paragraf. Setelah dapat membaca dengan lancar maka siswa baru dinaikkan ke level cerita. Jumlah siswa yang masuk dalam level cerita 2 cukup banyak yaitu sebesar $48 \%$ dari keseluruhan siswa. Siswa dapat dikategorikan berada di level cerita2 jika dapat membaca dengan lancar serta mampu menjawab pertanyaan yang diberikan, baik pertanyaan yang implisit maupun eksplisit. Jika siswa tidak mampu menjawab pertanyaan dengan benar maka siswa dimasukkan dalam level cerita 1 .

Paparan hasil penelitian tersebut menunjukkan rendahnya tingkat literasi dasar siswa di sekolah yang diteliti. Jumlah siswa secara keseluruhan yang dapat membaca dengan lancar hanya $60 \%$. Jumlah ini sangat rendah mengingat literasi dasar merupakan keterampilan dasar yang sangat penting. Terdapat $40 \%$ siswa yang terancam tidak tuntas dalam hal literasi dasar. Hal ini menunjukkan bahwa masih banyak siswa mengalami hambatan dalam membaca bacaan.

\section{Kemampuan siswa dalam membaca pemahaman dasar}

Masalah utama dalam literasi bukan hanya kemampuan membaca, tetapi juga dapat memahami isi bacaan. Indikator memahami isi bacaan adalah mampu menjawab pertanyaan yang tersurat maupun tersirat dalam bacaan. Memahami informasi yang terdapat dalam bacaan melalui menjawab pertanyaan merupakan salah satu indikator dasar dalam pemahaman literal. Pemahaman literal sendiri merupakan tahapan awal atau tahapan paling dasar dalam membaca pemahaman. Tahapan lanjutan setelah pemahaman literal adalah pemahaman inferensial atau tingkat interpretasi. Berikut ini dapat disajikan data 
siswa dalam bidang pemahaman literal berdasarkan hasil tes.

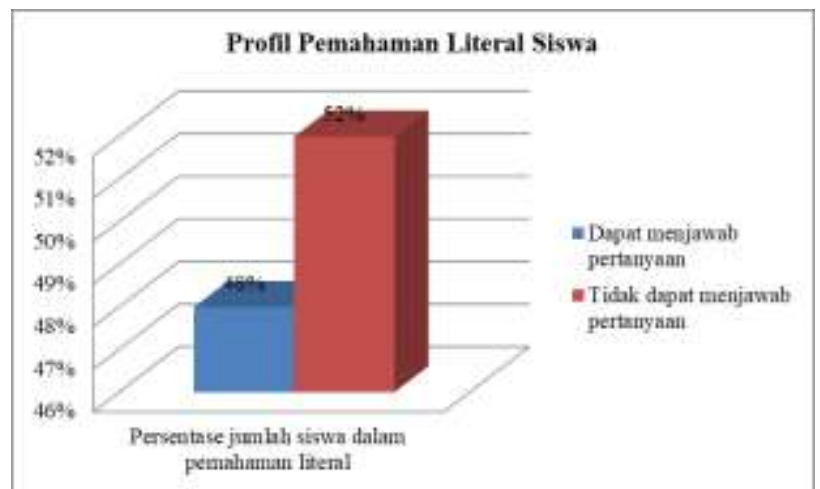

\section{Gambar 2. Profil Kemampuan Membaca Pemahaman Siswa}

Berdasarkan gambar 2 dapat diketahui jumlah siswa yang dapat memahami isi bacaan hanya sebesar 48\%, sedangkan 52\% diantaranya tidak dapat memahami isi bacaan ketika dilakukan tes. Sebagian besar siswa belum mampu memahami apa yang dibaca. Hal ini menunjukkan bahwa dalam tingkat pemahaman literal atau yang paling dasar siswa belum mampu. Terlebih lagi dalam tingkat pemahaman lanjutan, dapat dipastikan siswa belum bisa mencapai tahapan tersebut. Hal ini berkaitan dengan kemampuan siswa dalam mengetahui makna kata, memahami susunan bacaan, kemampuan menyeleksi gagasan pokok, kemampuan menyimpulkan isi bacaan dan mengingat kembali apa yang tertulis dalam bacaan. Salah satu faktor yang menyebabkan siswa tidak mampu memahami isi bacaan dikarenakan tidak dapat membaca dengan lancar. Masalah utamanya adalah kemampuan membaca yang masih rendah, maka dari itu tidak mengherankan jika siswa tidak dapat memahami isi bacaan. Namun demikian terdapat juga sekelompok siswa yang telah lancar membaca tetapi tidak memahami apa yang dibaca. Jumlahnya cukup besar yaitu sekitar $12 \%$ dari keseluruhan siswa. Siswa yang termasuk dalam kategori ini adalah siswa yang berada dilevel cerita 1. Siswa yang dimasukkan ke dalam level cerita 1 adalah siswa yang telah lancar membaca tetapi tidak mampu menjawab dengan benar ketika diberikan pertanyaan berdasarkan teks. Menurut hasil wawancara dengan guru, selain siswa kurang lancar membaca faktor lain yang meyebabkan siswa tidak mampu memahami isi bacaan karena terkendala bahasa. Kemampuan siswa dalam berbahasa Indonesia masih rendah. Agar bacaan dapat dipahami siswa seorang guru seringkali harus menerjemahkan terlebih dahulu ke bahasa daerah.

Berdasarkan profil kemampuan literasi siswa yang sangat beragam di era pandemi, harus ada gebrakan untuk mendongkrak kemampuan literasi siswa. Terlebih lagi dengan tidak meratanya kemampuan membaca siswa pada masing-masing kelas dibutuhkan pendekatan baru dalam pembelajaran literasi. Salah satu solusi yang dapat digunakan adalah menggunakan buku bacaan berjenjang (Soemitra, 2016). Melalui buku ini siswa dapat belajar sesuai levelnya. Salah satu tujuannya adalah mengurangi rasa bosan dan meningkatkan motivasi belajar membaca. Selain itu peran orang tua dalam pembelajaran di era pandemi harus dioptimalkan. Orang tua harus dilibatkan dalam proses bimbingan dan pembiasaan budaya literasi di rumah (Rahmawati, Fartiwi, \& Fatimah, 2020).

Pada dasarnya angka melek huruf di Indonesia sudah tinggi. Hal ini merupakan modal yang sangat penting dalam pengembangan budaya literasi. Kendatipun demikian, minat baca yang dimiliki masih 
rendah. Berdasarkan hasil penelitian PIRLS (Progress in International Reading Literacy Study) minat baca masyarakat Indonesia masih berada di bawah rata-rata dunia (Wulandari, 2017). Maka dari itu gerakan literasi sekolah harus lebih ditingkatkan, meskipun dalam kondisi pandemi. Pengembangan budaya literasi harus tetap dilakukan bagaimanapun tantangan yang dihadapi. Namun demikian persoalan utama dalam literasi adalah kemampuan membaca. Tanpa bisa membaca kampanye literasi yang diprogramkan tidak akan berhasil, oleh karena itu kemampuan membaca siswa di era pandemi ini harus diperhatikan. Ancaman learning loss selama pandemi harus segera diantisipasi (Engzell, Frey, \& Verhagen, 2021). Salah satu upaya minimal yang harus dipertahankan adalah berkaitan dengan kemampuan literasi dasar, karena kemampuan tersebut merupakan kemampuan paling mendasar dalam tahapan belajar siswa.

\section{SIMPULAN DAN REKOMENDASI}

Berdasarkan uraian pada hasil dan pembahasan dapat disimpulkan bahwa kemampuan literasi dasar siswa perlu ditingkatkan. Selama pembelajaran di era pandemi banyak ditemui siswa yang tidak lancar membaca. Hasil survei memperlihatkan bahwa jumlah siswa di level pemula sebanyak $7 \%$, pada level huruf $10 \%$, pada level kata sebanyak $11 \%$, level paragraf $12 \%$, level cerita 1 sebanyak $12 \%$ dan level cerita 2 sebanyak 48\%. Dalam hal membaca pemahaman juga perlu ditingkatkan. Hanya sedikit siswa yang lancar membaca dan mampu memahami isi bacaan. Sebagian besar siswa belum memahami isi bacaan karena belum lancar membaca dan terkendala penggunaan bahasa.

Berdasarkan kesimpulan yang telah disampaikan terdapat beberapa saran yang dapat diberikan. Pertama, kemampuan literasi dasar siswa perlu ditingkatkan dengan berbagai upaya seperti pembiasaan, perubahan metode pembelajaran dan peningkatan intensitas pembelajaran literasi. Kedua, perlu adanya pendekatan baru dalam pembelajaran literasi yaitu guru hendaknya mengajar literasi di level yang tepat agar siswa tidak merasa bosan dalam belajar. Ketiga, selama pandemi pembelajaran literasi hendaknya diutamakan, terutama pada kelas bawah agar jumlah siswa yang tidak membaca berkurang.

\section{DAFTAR PUSTAKA}

Antoro, B. (2017). Gerakan Literasi Sekolah. Dari pucuk hingga akar. https://doi.org/10.1017/S00332917000 36606

Batubara, H. H., \& Ariani, D. N. (2018). Implementasi Program Gerakan Literasi Sekolah Di Sekolah Dasar Negeri Gugus Sungai Miai Banjarmasin. Jurnal Pendidikan Sekolah Dasar, 4(1), 15. https://doi.org/10.30870/jpsd.v4i1.296 5

Budiati, B. (2013). The Dual Purpose of Teaching Literature: to Provide Stimulating Course Content and to Develop Students' Communicative Abilities. Jurnal Sosial Humaniora, 6(2), 100-111. https://doi.org/10.12962/j24433527.v6i 2.600

Endiawan, A. S., Fathurohman, I., \& Santoso, S. (2020). The Development Of Literacy Learning Media Of Illustrated Story Based On Android E-Book Toward Reading Interest Of Third Grade Students. Primary: Jurnal Pendidikan Guru Sekolah Dasar, 9(4), 564-570.

https://doi.org/10.33578/jpfkip.v9i4.79 94

Engzell, P., Frey, A., \& Verhagen, M. D. (2021). Learning loss due to school closures during the COVID-19 pandemic. Proceedings of the National Academy of Sciences, 118(17), e2022376118.

https://doi.org/10.1073/pnas.20223761 18 
Indahri, Y. (2020). Permasalahan Pembelajaran Jarak Jauh Di Era Pandemi. Pusat Penelitian Badan Keahlian DPR R, 19, 13-18. Retrieved from

https://berkas.dpr.go.id/puslit/files/info _singkat/Info Singkat-XII-12-II-P3DIJuni-2020-201.pdf

Juliswara, V. (2017). Mengembangkan Model Literasi Media yang Berkebhinnekaan dalam Menganalisis Informasi Berita Palsu (Hoax) di Media Sosial. Jurnal Pemikiran Sosiologi, 4(2), 142. https://doi.org/10.22146/jps.v4i2.2858 6

Lilawati, A. (2020). Peran Orang Tua dalam Mendukung Kegiatan Pembelajaran di Rumah pada Masa Pandemi. Jurnal Obsesi : Jurnal Pendidikan Anak Usia Dini, 5(1), 549. https://doi.org/10.31004/obsesi.v5i1.63 0

Rahmawati, T., Fartiwi, \& Fatimah, U. N. (2020). Model Pendampingan Belajar Orang Tua untuk Anak Berkebutuhan Khusus Selama Masa Pandemi. Academica: Journal of Multidisciplinary Studies Editorial, 4(2), 257-266.

Ratnawati, L. A. (2018). Implementasi Gerakan Literasi Sekolah Di SD Negeri Bhayangkara Yogyakarta. Basic Education, 7(36). Retrieved from

http://journal.student.uny.ac.id/ojs/index.php/pgsd/article/viewFile/14003/ 13534

Saleh, M. (2020). Merdeka Belajar di Tengah Pandemi Covid-19. Prosiding Seminar Nasional Hardiknas, 51-56.

Saryono, D., Ibrahim, G. A. I., Muliastuti, L., Akbari, Q. S. A., Hanifah, N.,
Miftahussururi, E. (2017). Materi Pendukung Literasi Baca-Tulis. Jakarta: Gerakan Literasi Nasional.

Soemitra, Y. T. (2016). Buku Bacaan Berjenjang Tingkatkan Literasi Siapkan Guru Profesional. Prioritaskeun, pp. 1-12.

Sujana, A., \& Rachmatin, D. (2019). Literasi digital abad 21 bagi mahasiswa PGSD : apa , mengapa , dan bagaimana. Current Research in Education: Conference Series Journal, 1(1), 1-7.

Sutisna, D., \& Widodo, A. (2020). Peran Kompetensi Guru Sekolah Dasar Dalam Meningkatkan Efektivitas Pembelajaran Daring. Jurnal Bahana Manajemen Pendidikan, 9(2), 58-64. https://doi.org/https://doi.org/10.24036 /jbmp.v9i2.110927

Suyono, Harsiati, T., \& Wulandari, I. S. (2014). Implementasi gerakan literasi sekolah pada pembelajaran tematik di sekolah dasar. Jippsd, 2(1), 116-123.

Wiedarti, P., \& Laksono, K. (2016). Panduan gerakan literasi sekolah di sekolah dasar. In Direktorat Pembinaan Sekolah Dasar Direktorat Jenderal Pendidikan Dasar dan Menengah Kementerian Pendidikan dan Kebudayaan. https://doi.org/10.1007/s10029-017$1595-\mathrm{x}$

Wulandari, R. (2017). Implementasi Kebijakan Gerakan Literasi Sekolah Di Sekolah. Jurnal Kebijakan Pendidikan UNY, VI (3). Retrieved from http://journal.student.uny.ac.id/ojs/ojs/i ndex.php/sakp/article/viewFile/9256/8 938 